Meta

Journal des traducteurs

Translators' Journal

\title{
Leveraging Virtual Learning Environments for Training Interpreter Trainers
}

\author{
Barbara Moser-Mercer, Barbara Class et Kilian G. Seeber
}

Volume 50, numéro 4, décembre 2005

Pour une traductologie proactive - Actes

For a Proactive Translatology - Proceedings

Por una traductología proactiva - Actas

URI : https://id.erudit.org/iderudit/019872ar

DOI : https://doi.org/10.7202/019872ar

Aller au sommaire du numéro

Éditeur(s)

Les Presses de l'Université de Montréal

ISSN

0026-0452 (imprimé)

1492-1421 (numérique)

Découvrir la revue

Citer cet article

Moser-Mercer, B., Class, B. \& Seeber, K. G. (2005). Leveraging Virtual Learning Environments for Training Interpreter Trainers. Meta, 50(4).

https://doi.org/10.7202/019872ar
Résumé de l'article

La demande d'interprètes de conférence dans les langues les plus répandues est en baisse. Par contre, la demande ne cesse de croître dans des langues moins utilisées, notamment lors de chaque élargissement de l'UE. En parallèle, sur la scène internationale, la demande d'interprètes qualifiés ne cesse d'augmenter que ce soit dans des opérations de maintien de la paix ou dans des tribunaux de crime de guerre. Cette donne contribue à un besoin accru en formateurs d'interprètes tant pour des formations traditionnelles que pour des formations intensives et ponctuelles. Les interprètes forment un corps professionnel très mobile et de ce fait, il est difficile de les mobiliser pour de longues périodes de formation. Le cours du Certificat de formateurs d'interprète dispensé par l'ETI (Université de Genève) est le seul cours postgrade du genre depuis 1996. Pour répondre à la demande venue du monde entier, le cours est maintenant offert dans un format hybride, alliant neuf mois de distance à une semaine présentielle à Genève. Le portail utilisé (www.unige.ch/eti/certificate/training) offre un environnement d'apprentissage collaboratif élaboré. De part son interface accessible à tout public et une section réservée aux étudiants en interprétation, il devient un espace de rencontre entre différentes communautés. Cet article présente les premiers résultats obtenus, au niveau de l'environnement d'apprentissage et au niveau de l'apprentissage lui-même.
Ce document est protégé par la loi sur le droit d'auteur. L'utilisation des services d'Érudit (y compris la reproduction) est assujettie à sa politique d'utilisation que vous pouvez consulter en ligne.

https://apropos.erudit.org/fr/usagers/politique-dutilisation/ 


\title{
Leveraging Virtual Learning Environments for Training Interpreter Trainers
}

\author{
Barbara Moser-Mercer, Barbara Class, Kilian G. Seeber \\ University of Geneva, Geneva, Switzerland \\ barbara.moser@eti.unige.ch
}

\begin{abstract}
RÉSUMÉ
La demande d'interprètes de conférence dans les langues les plus répandues est en baisse. Par contre, la demande ne cesse de croître dans des langues moins utilisées, notamment lors de chaque élargissement de l'UE. En parallèle, sur la scène internationale, la demande d'interprètes qualifiés ne cesse d'augmenter que ce soit dans des opérations de maintien de la paix ou dans des tribunaux de crime de guerre. Cette donne contribue à un besoin accru en formateurs d'interprètes tant pour des formations traditionnelles que pour des formations intensives et ponctuelles. Les interprètes forment un corps professionnel très mobile et de ce fait, il est difficile de les mobiliser pour de longues périodes de formation. Le cours du Certificat de formateurs d'interprète dispensé par l'ETI (Université de Genève) est le seul cours postgrade du genre depuis 1996. Pour répondre à la demande venue du monde entier, le cours est maintenant offert dans un format hybride, alliant neuf mois de distance à une semaine présentielle à Genève. Le portail utilisé (www.unige.ch/eti/certificate/training) offre un environnement d'apprentissage collaboratif élaboré. De part son interface accessible à tout public et une section réservée aux étudiants en interprétation, il devient un espace de rencontre entre différentes communautés. Cet article présente les premiers résultats obtenus, au niveau de l'environnement d'apprentissage et au niveau de l'apprentissage luimême.
\end{abstract}

\begin{abstract}
While the demand for conference interpreters in traditional language combinations (the more widely used languages) is decreasing, the need for experts in less widely used languages is rapidly increasing with each enlargement of the EU. Post-war peace-keeping operations as well as warcrime tribunals have also increased the need for high-level interpreters in languages hitherto not used in the international arena and consequently more well-trained interpreter trainers both for traditional programs as well as ad-hoc intensive programs must be available. Interpreters are a highly mobile community of professionals, unable to be physically present in a university for long periods of time to be trained as trainers. The Certificate course for Interpreter Trainers at ETI (University of Geneva) has been offering the only postgraduate course for training interpreter trainers since 1996. To meet the demand for training around the world the Certificate course is now offered in a blended format: Nine months of distance learning are blended with one week of faceto-face learning. The portal (www.unige.ch/eti/certificate/training) offers a rich learning environment with a number of tools to implement the philosophy of collaborative learning. With its public access and a special section for students of interpreting the portal has become an international meeting point for interpreter trainers where participants in the Certificate course interact with interpreting students at ETI, and interpreter trainers from schools around the world can interact with the Certificate teaching staff and students. This paper reports on the first systematic assessment of both the learning environment and the learning outcomes of the Certificate course.
\end{abstract}




\section{MOTS-CLÉS/KEYWORDS}

training interpreter trainers, blended learning, e-learning, collaborative learning, socio-constructivist learning

\section{Introduction}

The Certificate course for interpreter trainers at the Ecole de traduction et d'interprétation (ETI) of the University of Geneva was founded in 1996 on the belief that interpreting can be taught and learned, provided students showed sufficient language proficiency and aptitude (however the latter may be defined), but that most teaching had hitherto been hit or miss or, worse yet, built on the assumption that the "interpreter-teacher knows best". We did not feel that interpreting could be learned solely by copying a teacher who was passing on his own solutions and rules. Instead, we felt that as trainers we should focus our interventions on helping students unfold their potentials. We believe, as Piaget (Piaget and Inhelder, 1948) and Papert (1980) do, that knowledge is actively constructed by the student and future trainer in interaction with his learning environment and that it is our responsibility to create a rich environment to fuel the constructive process. This might be at the cost of letting participants and future trainers "rediscover the wheel" or drift away when shortcuts might be available.

Although there is certainly nothing wrong with showing students and trainers the right way of doing things or in letting them discover things for themselves, this can become a formula for disaster when worldviews are at odds, value systems clash, or when some unpopular views stubbornly persist within a community. This is when we have to question our assumption about being the most qualified to tell our students and future trainers how to learn, how to accomplish a task, how to develop a skill. This is particularly dangerous in a multi-cultural setting where different value systems have to learn to co-exist. Indeed, the world of conference interpreting is characterized by cultural diversity at every level: the delegates, the interpreters, the trainers and researchers.

We also believe that expert performance, as Ericsson (2004) puts it, is mediated by "complex integrated systems of representations for the execution, monitoring, planning, and analyses of performance", and that attaining such a high level of expertise requires an orderly and deliberate approach. Deliberate practice is designed to improve specific aspects of performance in a way that improvements can be successfully integrated into reproducible expert performance. Ericsson (2004) clearly states that,

[...] practice aimed at improving integrated performance cannot be performed mindlessly or independent of the representative context for the target performance. More accomplished individuals in the domain, ideally professional coaches and teachers, will play an essential role in guiding the future experts to acquire superior performance... [experimental studies have uncovered] the complex mechanisms that mediate this level of superior achievement. These mechanisms are not the result of mere experience. Rather, their development requires engagement in deliberate practice that gradually builds complex integrated systems of representations for the execution, monitoring, planning, and evaluation of actions. (Ericsson, 2004:74)

When training for expert performance we are also mindful of the more recent distinction being made between routine and adaptive expertise. The key difference between routine and adaptive experts is the greater capacity of the latter to transfer learning to novel tasks within and beyond the initial domain (Hatano and Inagaki, 1986). Adaptive experts have a deeper conceptual understanding of the domain, possessing not just "know-how" and "know-what", but also "know-why". Kimball and Holyoak (2000) state that,

[...] one might expect adaptive expertise to develop to a greater degree for tasks that are variable rather than stereotyped in nature, and to emerge from free exploration more than from direct focus on achieving highly specific goals. Such conditions would be conducive to the development of more abstract, structural representations of domain knowledge, which would in turn better enable application of domain knowledge to novel situations that vary in surface characteristics from previously encountered situations. (Kimball and Holyoak, 2000:118) 
It is not entirely coincidental that our university's strong tradition in research on human development and learning would inspire us to remain on the cutting edge of training and to constantly seek to improve our Certificate course for interpreter trainers despite the fact it had evolved into one of its kind, was not broke and thus did not need fixing.

Still, tradition and our love for teaching interpreting obliges and so we have found ourselves rethinking interpreter trainer education, imagining new learning environments and putting new tools, media, and technologies at the service of future interpreter trainers. Psychologists and pedagogues like Piaget and Papert remind us that learning, especially today, is much less about acquiring information or submitting to other people's ideas or values, than it is about putting one's own words to the world, or finding one's own voice, and exchanging our ideas with others. Piaget's constructivism was at the basis of Papert's constructionism (Papert worked with Piaget in Geneva in the 60s), which shares the constructivist view of learning as "building knowledge structures through progressive internalization of actions [...] It then adds the idea that this happens especially felicitously in a context where the learner is consciously engaged in constructing a public entity, whether it is a sand castle on the beach or a theory of the universe (Papert, 1991:1)". Papert's approach helps us understand how ideas get formed and transformed when expressed through different media, when actualized in a particular context, and when worked out by individual minds. Knowledge remains essentially grounded in contexts, and shaped by users, and the use of external supports and mediation remains crucial to expanding the potential of the human mind.

Speech and thought are thus essential in helping learners construct knowledge. Cognitive psychologists, like Vygotsky (1962) and Piaget, were concerned with speech and thought to the extent that speech is involved in communicating knowledge between people. But, more importantly, both were concerned with language and thought, that is, with the relations of inner linguistic and cognitive structures. For Vygotsky thought is not merely expressed in words, it comes into existence through them. Providing a learning environment that offers a large variety of opportunities for participants to express themselves freely or in a guided way through multiple activities thus promotes thinking.

The transition from a traditional face-to-face learning environment to a blended and socioconstructivist learning framework obligated the teaching staff to dive into the unknown, at the cost of experiencing a momentary sense of loss. But, we were assured, that was a crucial part of learning, as only a learner who has actually traveled through a world, by adopting different perspectives, or putting on different glasses, can engage in a dialogue between initially incompatible experiences. As long as one is immersed in the learning experience it is difficult to translate one's experience into a model. Yet, we have traveled most of the road of the new Certificate course and now have sufficient experience to somehow detach ourselves from time to time so that the new model can begin to gain a life of its own and to allow us to communicate our findings. This attempt at cognitive growth reflects the need for balance between change and invariance. As teaching staff we chose change, drastic change that is, but are definitely seeking a new balance and finding new learning opportunities as we go along. We decided to move away from content to process and emphasize the ability to communicate, especially across cultures, to further the ability to work in teams, and develop the ability to find, synthesize and manipulate information. We took solace in the findings that many of the best deliverers of blended collaborative learning are in their forties and fifties and people with little IT related skills, but with plenty of good people handling skills (Prendergast, 2004).

For the Certificate we therefore chose to work with a socio-constructivist learning framework and a Student-Centered Learning Environment (SCLE). We will define both these pedagogical and technological choices. We will then shift to the results of our first assessment of such a techno-pedagogical learning and teaching blend: the development of a community of practice and of distributed cognition. 


\section{Learning environment}

\subsection{Pedagogical philosophy}

The learning environment we propose is a Student-Centered Learning Environment (SCLE) as defined by Land and Hannafin (2000) and Jonassen and Land (2000). This type of learning environment is characterized by the following elements: the learner occupies a central place in the elaboration of his/her own knowledge and skills. Activities are anchored in real contexts. Emphasis is given to negotiating and understanding personal cognitive models as well as the broader cognitive context. Participants' experiences within learning activities are taken into account. Finally, technology is used to elaborate and support meta-cognitive processes. Learning theories supporting SCLEs share a unique epistemology which consists in defining the learning process as a voluntary, active, intentional and conscious act. Learning is thus composed of a set of activities driven towards intention, action and reflection (Jonassen and Land, 2000). We will report on the assessment of these parameters in the section on results.

The choice of such a learning environment for interpreter trainers is by no means haphazard. Further to the arguments advanced in the introduction to this paper, it is clearly anchored in our belief that each interpreting student brings a unique combination of cognitive strengths and weaknesses to the task of acquiring interpreting skills, that learning to interpret does not have to be a solitary activity, that participants should acquire meta-cognitive skills to learn to identify the problems they encounter during skill acquisition so as to optimize communication between learner and teacher and construct appropriate learning activities. By offering such a learning environment to future trainers we allow them to experience learning in much the same way we would like them to train future interpreters: as such, the medium becomes the message.

\subsection{Socio-constructivism and collaborative learning}

Socio-constructivism is the social variant of constructivism, a learning philosophy that emphasizes the learners' engagement in constructing knowledge and competence on the basis of what they already know. During this process the learner modifies existing mental schemata and constructs new ones. The social dimension result from two educational philosophies coming together, the cultural approach represented by Vygotsky (1978) and the Swiss School (Doise, 1981; PerretClermont, 2000): they both proceed on the belief that beyond the learners constructing their own knowledge individually, they also interact with their peers in order to check their newly developed cognitive schemata against the beliefs of their peers. This in turn develops the learners' ability to verbalize knowledge and to argue their point and promotes the conscious use of new knowledge structures as well as a clearer understanding of their limitations.

Collaborative learning can be seen as one instantiation of the socio-constructivist approach as it emphasizes and structures social interaction through the formation of specific rules and processes. Dillenbourg's (1999) theory of collaborative learning comprises four dimensions: 1) the criteria that define a collaborative learning situation, 2) interaction, 3) processes, and 4) effects. A learning situation can be defined as collaborative if and when all participants are more or less at the same level of cognitive development, are capable of engaging in the same types of activity, enjoy more or less the same status within their community, share a common goal and work together. An interaction can be defined as collaborative if and when learners' cognitive processes are disturbed, if and when peers communicate in a sustained manner and negotiate points of view and when no member of the community tries to impose his or her point of view. In other words, the members of the learning community establish common ground (grounding) and negotiate a common solution. Among the processes we encounter repeatedly in a socio-constructivist learning environment are induction, when learners try and accommodate their peer learners' cognitive overload; verbalization, i.e. consciously arguing one's point of view, and cognitive conflict. The results of such a collaborative effort are difficult to measure and quantify, as it is difficult to isolate all the variables; but research in this domain points to the potential for conceptual change and increased selfregulation. Collaborative learning requires on-going stock-taking of shared goals, constant efforts 
to ensure grounding, both of which in turn require the ability to manage information and knowledge.

\subsection{Tools}

The portal for the Certificate course uses PostNuke, a content management system available in the public domain which offers a variety of core functionalities and complementary tools allowing the online interaction between and among teachers, tutors and participants. Depending on the immediacy of this interaction, we can distinguish between synchronous and asynchronous tools. Whereas the former require users to be on-line at the same time, the latter do not. Having said that, some tools can be used both synchronously and asynchronously and thus constitute a hybrid category.

\subsubsection{Asynchronous tools}

News

The news system, an electronic notice board, was conceived for the publication of information regarding portal activities, e.g. collective feedback, syntheses and summaries of chat sessions, as well as digests of participants' productions.

Calendar

This interactive calendar highlights all important dates and portal related activities. When placing the cursor over a highlighted date a dialogue window displays a brief description of the event, e.g. the beginning or end of a module, a scheduled chat session or an activity deadline.

Library

Much like a regular library, the electronic library is a collection of digital resources (text files, audio files, video files etc.) for participants to download, such as required readings for particular modules as well as multimedia or PowerPoint presentations.

\section{Activity folder}

The concept behind the activity folder is not entirely dissimilar to that of the library, although the directionality is inverted. This file-upload system has the function of an electronic file cabinet and allows participants to upload the final product of their on-line activities, usually in form of a text or hypertext file.

\section{Forum}

A forum is an on-line discussion board allowing content to be posted organized by topics and structured in threads. As a dynamic tool the forum lends itself to on-line discussions and, using the file attachment option, it can be used for collaborative content creation. 


\section{Portfolio}

The portfolio is a personalized web space allowing participants to publish a brief introduction about themselves and set up links to their most valuable and pertinent contributions on the portal.

Journal

The journal tool is an online personal diary which participants, tutors and teachers are encouraged to use to verbalize their reflections on the Certificate. This meta-cognitive tool is both process and content oriented. The author can decide to make individual journal entries public (i.e. accessible and visible to participants, tutors and teachers alike) or private (i.e. accessible and visible to the author only).

\section{Shout box}

As the name suggests, this is a tool allowing users to post quick messages in a dialogue box on the portal to communicate with all users (hence "shout").

E-mail

Although undeniably the most popular tool for electronic messaging, this tool is hardly used for the online activities of the Certificate course, as it is difficult to reconcile with the underlying pedagogical philosophy of collaborative learning and community building.

\subsubsection{Synchronous tools}

Chat

A chat room is a location on the portal allowing users to communicate with each other about an agreed-upon topic in real time by typing messages which are almost instantly displayed on the screens of all those users who are in the same chat room.

Wiki

The WIKI (from Hawaiian "wiki wiki" for "quick") is a collaborative hypertext tool allowing users to create and edit Web page content. In other words, several users can work on (i.e. modify) one and the same document and save it on the server. Consequently, draft versions of documents no longer need to be circulated among group members as all users have online access to the most recent version.

Pager

The pager tool is an instant messaging tool that allows establishing instant contact with other online users and to communicate with them in real time over a pop-up window.

Who is on-line

This is an awareness tool to provide information about who is on-line on the portal at the same time. It supports the social dimension of the learning environment, especially when participants are scattered all around the world.

\subsubsection{Custom made tools}

Whereas most tools available on the portal are personalized adaptations of PostNuke modules, others were custom made to meet arising needs.

\section{Evaluation tool}

The evaluation tool was designed as an interactive tracking tool allowing teachers and tutors to track participants' online activities (i.e. their individual contributions on the forum as well as their individual or group activities in the activity folder). This tool allows teachers to keep a tab on the progress of individual participants. 
Templates

Teachers and tutors devised templates in order to provide cognitive scaffolding for particular portal activities and solicit focused answers. These templates allow easy comparison between answers and facilitate feedback and tracking.

\section{Course assessment}

\subsection{Research questions}

From the above description of the philosophical and educational underpinnings of the new Certificate course for interpreter trainers the authors identified six major research questions. The instruments for data collection were chosen from the literature on distance learning and supplemented to capture the unique environment of interpreter training. The questions are all related to the overall evaluation of the learning environment by participants.

1- Did participants perceive the learning environment as supporting socio-constructive learning? 2- According to participants, did teachers support participants in their endeavor to develop socioconstructive strategies?

3- Did the Tutoring Support Structure engineering tool help designers design an appropriate learning environment for the Certificate course?

4- Did participants acquire skills?

5- Did tools fulfill the pedagogical role they were designed for?

6- Which tools were used most frequently?

\subsection{Materials and methods}

This study was conducted to evaluate the satisfaction of participants involved in the first blended edition of the Certificate for Interpreter Trainers. It involves 21 participants, 16 females and 5 males aged between 25 and 55. Participants were asked to fill in a questionnaire (Annexe 1) at the end of the face-to-face week in Geneva. The following indices and grouped variables were constructed: 1) variables measuring teachers' behavior from the Dolmans questionnaire (Dolmans et al., 2003), 2) variables measuring a) relevance, b) reflection, c) interaction, d) tutor support and e) peer support from the COLLES questionnaire (Taylor and Maor, 2000), 8) variables measuring the socioconstructivist dimension of learning, 9) variables measuring skills acquired for participants with teaching experience (11 participants) and those without (10 participants), 10) variables measuring the use of tools and their pedagogical functionality.

\subsubsection{Questionnaires}

\subsubsection{COLLES questionnaire}

The Constructivist On-Line Learning Environment Survey (COLLES) questionnaire has been developed to "support the use of the World Wide Web (the Web) for teaching in higher education, especially for postgraduate professional development programs for which social constructivism is a key pedagogical referent." The questionnaire has six items (Taylor and Maor, 2000):

- Professional Relevance - the extent to which engagement in the on-line classroom environment is relevant to participants' professional worldviews and related practices.

- Reflective Thinking - the extent to which critical reflective thinking is occurring in association with online peer discussion.

- Interactivity - the extent to which communicative interactivity is occurring on-line between participants and between participants and tutors.

- Cognitive Demand - the extent to which challenges and communicative role modeling is provided by tutors.

- Affective Support - the extent to which sensitive and encouraging support is provided by peers. 
- Interpretation of Meaning - the extent to which participants and tutor co-construct meaning in a congruent and connected manner.

\subsubsection{Dolmans and al. questionnaire}

This questionnaire is an instrument to provide teachers with feedback about their performance in guiding small groups. The items of the instrument are derived from socio-constructive theories, implying that "teachers should stimulate participants towards constructive, self-directed, contextual and collaborative learning and should demonstrate adequate interpersonal behavior." The items of the questionnaire we used are related to:

- Constructive/active learning - the extent to which "teachers stimulate students to actively construct their own knowledge. Students should elaborate on and interpret information instead of knowing facts and should be encouraged to construct their own understanding".

- Self-directed learning - the extent to which "teachers help learners to become expert learners, i.e., learners that are self-directed and goal oriented, purposefully seeking out needed information". - Contextual learning - the extent to which "students are exposed to a professionally relevant context".

- Collaborative learning - the extent to which "students have a common goal, share responsibilities, are mutually dependent, and need to reach agreement through open interaction"

\subsubsection{3. "Customized" questions}

These include questions related to the Tutoring Support Structure, the engineering tool we used to design the entire course and learning environment, as well as questions measuring the degree to which the course is socio-constructivist. Additional questions relate to the pedagogical functionality and use of tools and about acquired skills.

\subsubsection{Data analysis}

Data have been processed using descriptive statistics, factorial analysis and correlation analysis. 


\subsubsection{Results and discussion}

\begin{tabular}{|l|c|c|c|c|c|}
\hline & $\mathrm{N}$ & Minimum & Maximum & Mean & Std. Deviation \\
\hline Relevance (COLLES) & 21 & 3.5 & 5.0 & 4.492 & .5657 \\
\hline Reflection (COLLES) & 21 & 3.0 & 5.0 & 4.250 & .6021 \\
\hline Interaction (COLLES) & 21 & 2.5 & 5.0 & 3.440 & .6750 \\
\hline Tutor Support (COLLES) & 21 & 2.5 & 5.0 & 4.060 & .7285 \\
\hline Peer Support (COLLES) & 21 & 2.3 & 5.0 & 3.278 & .6051 \\
\hline Making Sense (COLLES) & 21 & 2.5 & 5.0 & 4.012 & .6494 \\
\hline Teacher's behavior (Dolmans and al.) & 21 & 3.1 & 4.8 & 3.869 & .5417 \\
\hline Constructivist learning (customized) & 21 & 2.9 & 4.3 & 3.707 & .3872 \\
\hline Tutoring Support Structure (customized) & 21 & 3.4 & 5.0 & 4.363 & .4840 \\
\hline Tools: frequency of use (customized) & 13 & 2.1 & 3.4 & 2.642 & .3400 \\
\hline $\begin{array}{l}\text { Awareness tools: frequency of use } \\
\text { (customized) }\end{array}$ & 13 & 2.8 & 4.0 & 3.327 & .4608 \\
\hline Usage of tools (customized) & 13 & 1.0 & 2.0 & 1.579 & .3091 \\
\hline Tools: pedagogical functionality (customized) & 21 & 3.7 & 5.8 & 4.844 & .5226 \\
\hline $\begin{array}{l}\text { Skills acquired for teaching participants } \\
\text { (customized) }\end{array}$ & 11 & 3.5 & 6.0 & 4.864 & .6649 \\
\hline $\begin{array}{l}\text { Skills acquired for non teaching participants } \\
\text { (customized) }\end{array}$ & 10 & 4.0 & 5.8 & 4.950 & .5110 \\
\hline Valid N (listwise) & 0 & & & & \\
\hline
\end{tabular}




\section{Table 1. Means and SD per group of variables}

Results are discussed following the order of the six research questions listed above.

\subsubsection{The socio-constructive dimension}

The learning philosophy can be considered constructivist. The mean is 3.70 out of 5 and the standard deviation is small (.5) for customized questions measuring that variable. Variables from the COLLES grouped in the respective indices for relevance (M 4.92/5, SD .5), reflection (M 4.25/5, SD .6), and making sense (M 4.01/5, SD .6) confirm these results as do the Dolmans and al. variables measuring teachers' support (M 3.86/5, SD .5) from the point of view of teachers' strategies.

\subsection{The Tutoring Support Structure dimension}

With regard to the Tutoring Support Structure engineering tool, participants believe it was efficient in helping designers design an appropriate training context for this Certificate (M 4.36/5, SD .4).

3.2.2.1.3. The skills acquisition dimension

\begin{tabular}{|l|l|l|l|l|l|l|}
\hline & $\mathrm{N}$ & Mean & Std. Deviation & Minimum & Maximum \\
\hline & Valid & Missing & & & & \\
\hline $\begin{array}{l}\text { Skills acquired for teaching } \\
\text { participants }\end{array}$ & 11 & 10 & 4.864 & .6649 & 3.5 & 6.0 \\
\hline $\begin{array}{l}\text { Skills acquired for non } \\
\text { teaching participants }\end{array}$ & 10 & 11 & 4.950 & .5110 & 4.0 & 5.8 \\
\hline
\end{tabular}

\section{Table 2. Skills acquired}

Ratings for skills acquired both by participants already teaching and participants not yet teaching while taking the Certificate are rather high (M 4.86 /6, SD .06 and M 4.95/6, SD .5). Participants have acquired skills and want to know more about how to implement on-line teaching in their teaching career. 
3.2.1.4. Tools: the pedagogical dimension

\begin{tabular}{|l|c|c|c|c|c|c|}
\hline & \multicolumn{2}{|c|}{$\mathrm{N}$} & Mean & Std. Deviation & Minimum & Maximum \\
\hline & Valid & Missing & & & & \\
\hline Pedagogical functionality of the news & 20 & 1 & 4.75 & 1.070 & 3 & 6 \\
\hline Pedagogical functionality of the forum & 21 & 0 & 5.86 & .359 & 5 & 6 \\
\hline Pedagogical functionality of the chat & 21 & 0 & 5.10 & .889 & 4 & 6 \\
\hline Pedagogical functionality of the shoutbox & 20 & 1 & 5.00 & 1.170 & 2 & 6 \\
\hline $\begin{array}{l}\text { Pedagogical functionality of the instant } \\
\text { messenger-pager }\end{array}$ & 21 & 0 & 5.14 & 1.108 & 2 & 6 \\
\hline $\begin{array}{l}\text { Pedagogical functionality of the personal } \\
\text { messages }\end{array}$ & 21 & 0 & 5.43 & .811 & 3 & 6 \\
\hline \begin{tabular}{l} 
Pedagogical functionality of the wiki \\
\hline Pedagogical functionality of the calendar
\end{tabular} & 21 & 0 & 3.38 & 1.359 & 1 & 6 \\
\hline \begin{tabular}{l} 
Pedagogical functionality of the journal \\
\hline Pedagogical functionality of the library
\end{tabular} & 21 & 1 & 3.75 & 1.410 & 1 & 6 \\
\hline $\begin{array}{l}\text { Pedagogical functionality of the activity } \\
\text { folder }\end{array}$ & 21 & 0 & 5.38 & .590 & 4 & 6 \\
\hline $\begin{array}{l}\text { Pedagogical functionality of the portal } \\
\text { guide }\end{array}$ & 21 & 0 & 4.67 & 1.197 & 2 & 6 \\
\hline Pedagogical functionality of the portfolio & 21 & 0 & 3.81 & 1.401 & 1 & 6 \\
\hline $\begin{array}{l}\text { Pedagogical functionality of the chat } \\
\text { recording }\end{array}$ & 21 & 0 & 4.48 & 1.167 & 2 & 6 \\
\hline $\begin{array}{l}\text { Pedagogical functionality of the module } \\
\text { description }\end{array}$ & 21 & 0 & 5.38 & .805 & 4 & 6 \\
\hline $\begin{array}{l}\text { Pedagogical functionality of the social } \\
\text { awareness tool }\end{array}$ & 21 & 0 & 5.43 & .746 & 4 & 6 \\
\hline
\end{tabular}

\section{Table 3. Pedagogical Functionality of Tools}

From the participants' point of view the tools that fulfilled best the pedagogical functionality they were designed for are the forum (M 5.86/6, SD .3), the social awareness tool (M 5.43/6, SD .7), the library (M 5.38/6, SD .6), the activity folder (M 5.38/6, SD .5) and the module description tool (M $5.38 / 6, \mathrm{SD} .8)$. These are all core tools regarding content elaboration, processing and understanding.

Tools that have a high standard deviation which indicates differences in perception amongst participants are the following: the calendar (M 4.52/6, SD 1.5), the journal (M 3.75/6, SD 1.4), the portfolio (M 3.81/6, SD 1.4) and the instant messenger pager (M 5.14/6, SD 1.1). These are organizational, meta-cognitive and communication tools. 
3.2.2.1.5. Tools: the frequency of use dimension

\begin{tabular}{|l|c|c|c|c|c|c|}
\hline & \multicolumn{2}{|c|}{$\mathrm{N}$} & Mean & Std. Deviation & Minimum & Maximum \\
\hline & Valid & Missing & & & & \\
\hline Frequency of use of the news & 21 & 0 & 2.62 & 1.161 & 1 & 4 \\
\hline Frequency of use of the forum & 21 & 0 & 3.90 & .301 & 3 & 4 \\
\hline Frequency of use of the chat & 21 & 0 & 2.62 & .669 & 2 & 4 \\
\hline Frequency of use of the shoutbox & 21 & 0 & 2.19 & .928 & 1 & 4 \\
\hline $\begin{array}{l}\text { Frequency of use of the instant } \\
\text { messenger-pager }\end{array}$ & 21 & 0 & 2.24 & 1.044 & 1 & 4 \\
\hline $\begin{array}{l}\text { Frequency of use of the personal } \\
\text { messages }\end{array}$ & 21 & 0 & 2.86 & .573 & 2 & 4 \\
\hline Frequency of use of the wiki & 21 & 0 & 1.95 & .805 & 1 & 4 \\
\hline Frequency of use of the calendar & 21 & 0 & 2.33 & .856 & 1 & 4 \\
\hline Frequency of use of the journal & 21 & 0 & 2.19 & .873 & 1 & 4 \\
\hline Frequency of use of the library & 21 & 0 & 3.19 & .602 & 2 & 4 \\
\hline $\begin{array}{l}\text { Frequency of use of the activity } \\
\text { folder }\end{array}$ & 21 & 0 & 3.05 & .669 & 2 & 4 \\
\hline $\begin{array}{l}\text { Frequency of use of the portal } \\
\text { guide }\end{array}$ & 21 & 0 & 2.29 & .902 & 1 & 4 \\
\hline Frequency of use of the portfolio & 20 & 1 & 2.20 & .616 & 1 & 3 \\
\hline $\begin{array}{l}\text { Frequency of use of the chat } \\
\text { recording }\end{array}$ & 21 & 0 & 2.14 & .910 & 1 & 4 \\
\hline $\begin{array}{l}\text { Frequency of use of the module } \\
\text { description }\end{array}$ & 20 & 1 & 3.65 & .489 & 3 & 4 \\
\hline $\begin{array}{l}\text { Frequency of use of the forum } \\
\text { functionalities }\end{array}$ & 21 & 0 & 2.33 & 1.426 & 1 & 4 \\
\hline
\end{tabular}




\section{Table 4. Frequency of use of tools}

The most frequently used tool is definitely the forum with a very high and representative mean (3.90/4) and a very small standard deviation (.3). It is followed by the module description tool (M 3.65/4, SD .4), the library (M 3.19/4, SD .6), and the activity folder (M 3.05/4, SD .6).

Among awareness tools, the most frequently used is the social awareness tool (M 3.67/4, SD .5), with other awareness tools following close behind.

\begin{tabular}{|l|c|c|c|c|c|c|}
\hline & \multicolumn{2}{|c|}{$\mathrm{N}$} & Mean & Std. Deviation & Minimum & Maximum \\
\hline & Valid & Missing & & & & \\
\hline $\begin{array}{l}\text { Frequency of use of the social } \\
\text { awareness tool }\end{array}$ & & 0 & 3.67 & .577 & 2 & 4 \\
\hline $\begin{array}{l}\text { Frequency of use of the forum } \\
\text { awareness tools }\end{array}$ & 21 & 0 & 3.52 & .680 & 2 & 4 \\
\hline $\begin{array}{l}\text { Frequency of use of the private } \\
\text { messages awareness tool }\end{array}$ & 21 & 0 & 3.48 & .680 & 2 & 4 \\
\hline $\begin{array}{l}\text { Frequency of use of the activity folder } \\
\text { awareness tool }\end{array}$ & 21 & 0 & 2.57 & .811 & 1 & 4 \\
\hline
\end{tabular}

\section{Table 5. Frequency of use of awareness tools}

\subsection{Correlations}

The pedagogical functionality of tools has the highest number of significant correlations: it correlates highly with skills, $r=0.56(\mathrm{P}<0.01)$, relevance, $r=0.60(\mathrm{P}<0.01)$, tutor support, $\mathrm{r}=0.73$ $(\mathrm{P}<0.01)$, making sense, $r=0.55(\mathrm{P}<0.01)$, teachers' behavior, $\mathrm{r}=0.64(\mathrm{P}<0.01)$, and TSS engineering tool, $\mathrm{r}=0.67(\mathrm{P}<0.01)$.

These results are of major relevance for us because the pedagogical functionality of tools correlates both with the pedagogical design (TSS) we decided upon upfront, with the content and quality of human support during the course (relevance, tutor support, making sense, teacher's behavior) and finally with the skills participants acquired and can put to use after having taken the course. These results confirm that the learning environment's tools have fulfilled their pedagogical mission and that they supported the learning process in a satisfactory manner

The Tutoring Support Structure, with its seven dimensions (human resources, staff training, tutor roles, learning environment, tutor support tools, knowledge management and activity scaffolding tools) correlates highly with relevance, $r=0.69(\mathrm{P}<0.01)$, reflection, $\mathrm{r}=0.55,(\mathrm{P}<0.01)$, making sense, $r=0.56(\mathrm{P}<0.01)$, teacher's behavior, $r=0.72(\mathrm{P}<0.01)$, and the pedagogical functionality of tools, $\mathrm{r}=0.67(\mathrm{P}<0.01)$.

The correlation TSS-teacher's behavior relates to the human resources dimension: participants express their satisfaction with both the competence of staff and the fact that sufficient number of staff were available at all times. The correlation TSS-reflection/making sense points to the pertinence and usefulness of activity scaffolding tools (such as for example the templates that were used to provide a matrix for participants within which to structure their knowledge). The correlation TSS- pedagogical functionality of tools relates to both the learning environment and the knowledge management dimension. Participants are clearly satisfied with the way the learning environment was structured to allow for efficient and effective knowledge management.

Teacher's behavior correlates highly with tutor support, $r=0.70(\mathrm{P}<0.01), \mathrm{TSS}, \mathrm{r}=0.72$ $(\mathrm{P}<0.01)$, and the pedagogical functionality of tools, $r=0.64(\mathrm{P}<0.01)$. This confirms the correlations discussed above; this time however the focus is on the teacher, whose role was to facilitate knowledge construction and skill development. The teacher and the tutor worked in synergy, which greatly benefited participants. The human resources structure created for the course 
(Certificate course director, teacher staff and tutor) worked well. Finally this correlation indicates that teachers were well supported in their task by the tools that had been designed for the course.

Making sense correlates highly with relevance $r=0.66(\mathrm{P}<0.01), \mathrm{TSS}, \mathrm{r}=0.56(\mathrm{P}<0.01)$, and the pedagogical functionality of tools, $\mathrm{r}=0.55(\mathrm{P}<0.01)$.

By way of analogy to the previous discussion we can conclude that the course made sense and that participants find it professionally relevant. Pedagogical tools were relevant to the assigned activities.

Peer support correlates highly with interaction, $r=0.67(\mathrm{P}<0.01)$, which confirms that we have achieved the objectives of the socio-constructivist learning environment:

Reflection correlates highly with tutor support, $r=0.62(\mathrm{P}<0.01)$, and TSS, $r=0.55(\mathrm{P}<0.01)$. The correlation of reflection and TSS is not surprising since the course was designed to have a strong meta-cognitive component which is clearly confirmed by the data.

The significant correlation between reflection and tutor support can be interpreted as the tutors stimulating the participants' learning process and inviting participants to become reflective learners.

\section{Discussion}

Results show that the Certificate course provides for a learning experience which is almost always professionally relevant (M 4.49/6, SD .5). Taylor and al. (2000) obtained similar results: "Students expect their online learning almost always (mean $=4.8$ ) to be interesting and directly related to their professional practice; and they perceive that this occurs very often (mean $=4.3$ )". Results also show that learning is almost always self reflective (M 4.25/5, SD .6) and this again is in keeping with Taylor and al. (2000) who obtained similar results: "Students prefer to be engaged often (mean $=4.0$ ) in thinking critically about their own ideas and other students' ideas, and about how they are learning".

Scores obtained both for interaction (M 3.44/5, SD .6) and peer support (M 3.27/5, SD .7) are the lowest. Taylor and al. (2000) observe the same "anomaly": "Whereas we might expect that students would value highly the opportunity to interact often with fellow students, a general preference has been indicated for this to occur less than often (mean $=3.8$ ). Given that students were engaged online in structured small group interactions it is somewhat surprising that the class felt that they had the opportunity to engage in an exchange of ideas with other students only sometimes $($ mean $=3.1)$ ".

Scores obtained for the tutor support dimension are rather high, but with a fairly high standard deviation (M 4.06/5, SD .7). Our results vary from Taylor and al. (2000) for this dimension, who point out that "students' preference for the online tutor to quite frequently (mean = 3.8 ) provide cognitive support are close to being met in practice $($ mean $=3.6)$. Although they seem to value the tutor's role as challenging their assumptions, stimulating their thinking and modeling good discourse and reflective thinking, they don't want this to occur all the time". Interpreting our own results and looking at the high standard deviation for this variable, we believe that the reason for this result can be found in major differences in learners' profiles. Results similar to ours have, however, been obtained elsewhere (Class and Schneider, 2004). Some participants are more independent, whereas others prefer to rely on a tutor. Clearly, this dimension requires further research. 


\section{Conclusion}

This first evaluation of the new blended Certificate course for interpreter trainers offers valuable insights into how the various pedagogical options adopted at the outset impacted on the participants' experience. They rated the socio-constructive dimension of the course highly, which means that our major objective for re-designing the Certificate course has been met. Learners found efficient and effective support both in the learning environment and in the human resource organization, although there were differences in terms of use and appreciation. Clearly, participants acquired skills that are professionally relevant and immediately applicable in their respective teaching environment. Participants made appropriate and ample use of the various tools designed to support their learning experience, and it comes as no surprise that in a distributed learning environment, where course participants are spread around the globe, the social awareness tool would be highly appreciated and used most frequently. Clearly, in a socio-constructive learning environment, social awareness occupies a central place. Our assessment data reflect the range of evaluations one would expect given the variable cultural backgrounds of participants and the fact that only about $15 \%$ had any prior e-learning experience. Front-loading the course with a onemonth introduction to blended learning proved to be the best investment we could have made to ensure that the re-designed course would be successful: once participants knew their tools, the rest of the learning philosophy could unfold, both for staff and participants.

\section{REFERENCES}

Class, B., Moser-Mercer, B. and K. Seeber (2004): Blended learning for training interpreter trainers, In D. Remenyi (Ed.), 3rd European Conference on e-Learning, Paris, 25-26 November 2004, pp. 507-515, Reading, Academic Conferences Limited.

Class, B. et D. SCHNEIDER (2004): Tutorat, socio-constructivisme et capitalisation des connaissances dans un portail communautaire utilisé en éducation à distance, Colloque "L'industrialisation du tutorat en formation à distance", Poitiers. http://www.cned.fr/colloqueeifad/Documents/Class Schneider.pdf

Dillenbourg, P. (1999): What do you mean by "collaborative learning"?, Collaborative Learning, Cognitive and Computational Approaches, Oxford, Elsevier.

Doise, W. and G. Mugny (1981): Le développement social de l'intelligence, Paris, InterEditions.

Dolmans, D.H.J.M., WolfHagen, H.A.P., Scherpbier, A.J.J.A. and C.P.M. VAn DeR Vleuten (2003):

Development of an instrument to evaluate the effectiveness of teachers in guiding small groups, Higher Education 46, pp. 431-446.

ERICSSON, K.A. (2004): Deliberate practice and the acquisition and maintenance of expert performance in medicine and related domains, Academic Medicine 79-10, p. 70-81.

Hatano, G. and K. InAGaki (1986): Two course of expertise, In H. Stevenson, H. Azuma and K. Hakuta (Eds.), Child development and education in Japan, San Francisco, Freeman.

JonASSEN, D. H. and S. M. LAND (2000): Theoretical Foundations of Learning Environments. Mahwah, New Jersey, Lawrence Elbaum Associates.

Kimball, D.R. and K.J. HolyoAK (2000): Transfer and expertise, In E. Tulving and F.I.M. CRAIK (Eds.), The Oxford handbook of memory, Oxford, OUP.

LAND, S. M. and M. J. HANNAFIN (2000): Student-Centered Learning Environments, Theoretical Foundations of Learning Environments, Mahwah, New Jersey, Lawrence Elbaum Associates.

Moser-Mercer, B., Class, B. and K.G. SeEber (in press): Community building: Training interpreter trainers, Proceedings of the Fifth National Conference on Interpreting Practice, Pedagogy and Research, Shanghai, 5-7 November 2004.

Papert, S. (1980). Mindstorms. Children, computers and powerful ideas. New York: Basic Books. PiAget, J., and B. InHzELDER (1948): The child's conception of space, London, Routledge and Kegan. Perret-Clermont, A.-N. (2000): La construction de l'intelligence dans l'interaction sociale, Berne, Francfort, P. Lang.

Prendergast. G. (2004): Blended collaborative learning: On-line teaching of on-line educators, Global Educator. TAYLOR, P. and D. MAOR (2000): Assessing the efficacy of online teaching with the Constructivist On-Line Learning Environment Survey, In A. HERRMANN and M.M. KULSKI (Eds), Flexible Futures in Tertiary Teaching. 
Proceedings of the 9th Annual Teaching Learning Forum, 2-4 February 2000. Perth: Curtin University of Technology. http://lsn.curtin.edu.au/tlf/tlf2000/taylor.html

Vygotsky, L.S. (1962): Thought and language, Cambridge, MA, MIT Press.

Vygotsky, L.S. (1978): Mind in society: the development of higher psychological processes, Cambridge Mass., London, Harvard University Press.

\section{ANNEX 1}

\section{Questionnaire ETI Certificate Participants}

\section{Introduction}

The purpose of this questionnaire is to help us understand how well you liked the on-line delivery of the first blended edition of the Certificate for Interpreter Trainers. Each one of the 117 statements below asks about your experience in the on-line part of the Certificate. Data will be processed and published only statistically.

The following questions will be dealt with: personal information, teachers' behaviour, learning environment, tutoring support structure, tools and skills. Filling in this questionnaire will take you about 20 minutes.

Please be assured that your responses will be treated confidentially, and that they will not affect your assessment. Thank you very much for your cooperation.

\section{1) Personal information:}

\begin{tabular}{|c|c|c|c|c|c|c|c|c|}
\hline 1 & Name & & & & & & & \\
\hline 2 & Sex & Female & & & Male & & & \\
\hline 3 & Age & $20-25$ & $25-30$ & $30-35$ & $35-40$ & $40-45$ & $45-50$ & $50-55$ \\
\hline
\end{tabular}




\section{2) Teachers' behaviour}

Below you will find general statements about teachers' behaviour. Please indicate to what extent you agree or disagree with them? Please tick the appropriate circle on the scale (totally disagree - totally agree) for each statement.

\begin{tabular}{|c|c|c|c|c|c|c|}
\hline \multicolumn{2}{|c|}{$\begin{array}{l}\text { Statements: } \\
\text { Teachers stimulated us ... }\end{array}$} & \multirow{2}{*}{$\begin{array}{c}\begin{array}{c}\text { Totally } \\
\text { disagree }\end{array} \\
\mathbf{1} \\
\mathrm{O}\end{array}$} & \multirow{2}{*}{$\begin{array}{c}\text { Disagree } \\
\\
2 \\
\text { O } \\
\end{array}$} & \multirow{2}{*}{$\begin{array}{c}\text { Somewhat } \\
\text { agree } \\
\mathbf{3} \\
\text { O }\end{array}$} & \multirow{2}{*}{$\begin{array}{c}\text { Agree } \\
\begin{array}{r}\mathbf{4} \\
\mathrm{O}\end{array}\end{array}$} & \multirow{2}{*}{$\begin{array}{c}\begin{array}{c}\text { Totally } \\
\text { agree }\end{array} \\
\mathbf{5} \\
\text { O }\end{array}$} \\
\hline 4 & ... to search for explanations during discussion & & & & & \\
\hline 5 & $\begin{array}{l}\ldots \text { to summarize what we had learnt in our own } \\
\text { words }\end{array}$ & $\mathrm{O}$ & $\mathrm{O}$ & $\mathrm{O}$ & $\mathrm{O}$ & $\mathrm{O}$ \\
\hline 6 & $\begin{array}{l}\ldots \text { to search for links between issues discussed } \\
\text { in the tutorial group }\end{array}$ & $\mathrm{O}$ & $\mathrm{O}$ & $\mathrm{O}$ & $\mathrm{O}$ & $\mathrm{O}$ \\
\hline 7 & $\begin{array}{l}\ldots \text { to understand underlying } \\
\text { mechanisms/theories }\end{array}$ & $\mathrm{O}$ & $\mathrm{O}$ & $\mathrm{O}$ & $\mathrm{O}$ & $\mathrm{O}$ \\
\hline 8 & ... to pay attention to contradictory explanations & $\mathrm{O}$ & $\mathrm{O}$ & $\mathrm{O}$ & $\mathrm{O}$ & $\mathrm{O}$ \\
\hline 9 & ... to generate clear learning issues by ourselves & $\mathrm{O}$ & $\mathrm{O}$ & $\mathrm{O}$ & $\mathrm{O}$ & $\mathrm{O}$ \\
\hline 10 & $\begin{array}{l}\text {... to evaluate our understanding of the subject } \\
\text { matter by ourselves }\end{array}$ & $\mathrm{O}$ & $\mathrm{O}$ & $\mathrm{O}$ & $\mathrm{O}$ & $\mathrm{O}$ \\
\hline 11 & ... to apply knowledge to the problem discussed & $\mathrm{O}$ & $\mathrm{O}$ & $\mathrm{O}$ & $\mathrm{O}$ & $\mathrm{O}$ \\
\hline 12 & $\begin{array}{l}\ldots \text { to apply knowledge to other } \\
\text { situations/problems }\end{array}$ & $\mathrm{O}$ & $\mathrm{O}$ & $\mathrm{O}$ & $\mathrm{O}$ & $\mathrm{O}$ \\
\hline 13 & ... to ask sophisticated questions & $\mathrm{O}$ & $\mathrm{O}$ & $\mathrm{O}$ & $\mathrm{O}$ & $\mathrm{O}$ \\
\hline 14 & ... to reconsider earlier explanations & $\mathrm{O}$ & $\mathrm{O}$ & $\mathrm{O}$ & $\mathrm{O}$ & $\mathrm{O}$ \\
\hline 15 & $\begin{array}{l}\ldots \text { to think about our strengths and weaknesses } \\
\text { concerning our functioning in the tutorial group }\end{array}$ & $\mathrm{O}$ & $\mathrm{O}$ & $\mathrm{O}$ & $\mathrm{O}$ & $\mathrm{O}$ \\
\hline 16 & $\begin{array}{l}\ldots \text { to give constructive feedback about our } \\
\text { group work }\end{array}$ & $\mathrm{O}$ & $\mathrm{O}$ & $\mathrm{O}$ & $\mathrm{O}$ & $\mathrm{O}$ \\
\hline 17 & ... to evaluate our group cooperation regularly & $\mathrm{O}$ & $\mathrm{O}$ & $\mathrm{O}$ & $\mathrm{O}$ & $\mathrm{O}$ \\
\hline 18 & $\begin{array}{l}\ldots \text { to arrange meetings with him/her to discuss } \\
\text { how to improve our functioning as a group }\end{array}$ & $\mathrm{O}$ & $\mathrm{O}$ & $\mathrm{O}$ & $\mathrm{O}$ & $\mathrm{O}$ \\
\hline
\end{tabular}




\section{3) Learning environment}

Below you will find statements about the learning environment. Please tick the appropriate circle on the scale (almost never - almost always) for each statement.

\begin{tabular}{|c|c|c|c|c|c|c|}
\hline \multicolumn{2}{|c|}{$\begin{array}{l}\text { Statements: } \\
\text { In the Certificate... }\end{array}$} & \multirow{2}{*}{$\begin{array}{c}\text { Almost } \\
\text { Never } \\
1 \\
O\end{array}$} & \multirow{2}{*}{$\begin{array}{c}\text { Seldom } \\
\mathbf{2} \\
\mathrm{O}\end{array}$} & \multirow{2}{*}{$\begin{array}{c}\text { Some-times } \\
\mathbf{3} \\
\mathrm{O}\end{array}$} & \multirow{2}{*}{$\begin{array}{c}\text { Often } \\
4 \\
\mathrm{O}\end{array}$} & \multirow{2}{*}{$\begin{array}{c}\text { Almost } \\
\text { Always } \\
\mathbf{5} \\
\mathrm{O}\end{array}$} \\
\hline 19 & $\begin{array}{l}\text {... my learning focuses on issues that interest } \\
\text { me. }\end{array}$ & & & & & \\
\hline 20 & $\begin{array}{l}\ldots \text { what I learn is important for my professional } \\
\text { practice as a trainer. }\end{array}$ & $\mathrm{O}$ & $\mathrm{O}$ & $\mathrm{O}$ & $\mathrm{O}$ & $\mathrm{O}$ \\
\hline 21 & $\begin{array}{l}\text {.. I learn how to improve my professional } \\
\text { practice as a trainer. }\end{array}$ & $\mathrm{O}$ & $\mathrm{O}$ & $\mathrm{O}$ & $\mathrm{O}$ & $\mathrm{O}$ \\
\hline 22 & $\begin{array}{l}\text {... what I learn connects well with my } \\
\text { professional practice as a trainer. }\end{array}$ & $\mathrm{O}$ & $\mathrm{O}$ & $\mathrm{O}$ & $\mathrm{O}$ & $\mathrm{O}$ \\
\hline 23 & ... I think critically about how I learn. & $\mathrm{O}$ & $\mathrm{O}$ & $\mathrm{O}$ & $\mathrm{O}$ & $\mathrm{O}$ \\
\hline 24 & ... I think critically about my own ideas. & $\mathrm{O}$ & $\mathrm{O}$ & $\mathrm{O}$ & $\mathrm{O}$ & $\mathrm{O}$ \\
\hline 25 & ... I think critically about other students' ideas. & $\mathrm{O}$ & $\mathrm{O}$ & $\mathrm{O}$ & $\mathrm{O}$ & $\mathrm{O}$ \\
\hline 26 & ... I think critically about ideas in the readings. & $\mathrm{O}$ & $\mathrm{O}$ & $\mathrm{O}$ & $\mathrm{O}$ & $\mathrm{O}$ \\
\hline 27 & ... I explain my ideas to other students. & $\mathrm{O}$ & $\mathrm{O}$ & $\mathrm{O}$ & $\mathrm{O}$ & $\mathrm{O}$ \\
\hline 28 & ... I ask other students to explain their ideas. & $\mathrm{O}$ & $\mathrm{O}$ & $\mathrm{O}$ & $\mathrm{O}$ & $\mathrm{O}$ \\
\hline 29 & $\ldots$ other students ask me to explain my ideas. & $\mathrm{O}$ & $\mathrm{O}$ & $\mathrm{O}$ & $\mathrm{O}$ & $\mathrm{O}$ \\
\hline 30 & ... other students respond to my ideas. & $\mathrm{O}$ & $\mathrm{O}$ & $\mathrm{O}$ & $\mathrm{O}$ & $\mathrm{O}$ \\
\hline 31 & ... the tutor/teacher stimulates my thinking. & $\mathrm{O}$ & $\mathrm{O}$ & $\mathrm{O}$ & $\mathrm{O}$ & $\mathrm{O}$ \\
\hline 32 & ... the tutor/teacher encourages me to participate. & $\mathrm{O}$ & $\mathrm{O}$ & $\mathrm{O}$ & $\mathrm{O}$ & $\mathrm{O}$ \\
\hline 33 & $\begin{array}{l}\ldots \text { the tutor/teacher models appropriate } \\
\text { discourse. }\end{array}$ & $\mathrm{O}$ & $\mathrm{O}$ & $\mathrm{O}$ & $\mathrm{O}$ & $\mathrm{O}$ \\
\hline 34 & $\begin{array}{l}\ldots \text { the tutor/teacher models critical self- } \\
\text { reflection. }\end{array}$ & $\mathrm{O}$ & $\mathrm{O}$ & $\mathrm{O}$ & $\mathrm{O}$ & $\mathrm{O}$ \\
\hline 35 & ... other students encourage my participation. & $\mathrm{O}$ & $\mathrm{O}$ & $\mathrm{O}$ & $\mathrm{O}$ & $\mathrm{O}$ \\
\hline 36 & $\ldots$ other students praise my contribution. & $\mathrm{O}$ & $\mathrm{O}$ & $\mathrm{O}$ & $\mathrm{O}$ & $\mathrm{O}$ \\
\hline 37 & ... other students value my contribution. & $\mathrm{O}$ & $\mathrm{O}$ & $\mathrm{O}$ & $\mathrm{O}$ & $\mathrm{O}$ \\
\hline 38 & $\begin{array}{l}\text {.. other students empathise with my struggle to } \\
\text { learn. }\end{array}$ & $\mathrm{O}$ & $\mathrm{O}$ & $\mathrm{O}$ & $\mathrm{O}$ & $\mathrm{O}$ \\
\hline 39 & $\begin{array}{l}\text {... I make good sense of other students' } \\
\text { messages. }\end{array}$ & $\mathrm{O}$ & $\mathrm{O}$ & $\mathrm{O}$ & $\mathrm{O}$ & $\mathrm{O}$ \\
\hline 40 & $\begin{array}{l}\text {... other students make good sense of my } \\
\text { messages. }\end{array}$ & $\mathrm{O}$ & $\mathrm{O}$ & $\mathrm{O}$ & $\mathrm{O}$ & $\mathrm{O}$ \\
\hline 41 & ... I make good sense of the tutor's messages. & $\mathrm{O}$ & $\mathrm{O}$ & $\mathrm{O}$ & $\mathrm{O}$ & $\mathrm{O}$ \\
\hline 42 & $\ldots$ the tutor makes good sense of my messages. & $\mathrm{O}$ & $\mathrm{O}$ & $\mathrm{O}$ & $\mathrm{O}$ & $\mathrm{O}$ \\
\hline
\end{tabular}

Here are some more statements about the learning environment. Please tick the appropriate circle on the scale (totally disagree - totally agree) for each statement. 


\begin{tabular}{|c|c|c|c|c|c|c|}
\hline \multicolumn{2}{|c|}{$\begin{array}{l}\text { Statements: } \\
\text { In the Certificate... }\end{array}$} & \multirow{2}{*}{$\begin{array}{c}\begin{array}{c}\text { Totally } \\
\text { disagree }\end{array} \\
\mathbf{1} \\
\text { O }\end{array}$} & \multirow{2}{*}{$\begin{array}{c}\text { Disagree } \\
\begin{array}{c}\mathbf{2} \\
\mathrm{O}\end{array}\end{array}$} & \multirow{2}{*}{$\begin{array}{c}\text { Somewhat } \\
\text { agree } \\
\\
\mathbf{3} \\
\mathrm{O}\end{array}$} & \multirow{2}{*}{$\begin{array}{c}\text { Agree } \\
\qquad \begin{array}{c}\mathbf{4} \\
\mathrm{O}\end{array}\end{array}$} & \multirow{2}{*}{$\begin{array}{c}\begin{array}{c}\text { Totally } \\
\text { agree }\end{array} \\
5 \\
\text { O }\end{array}$} \\
\hline 43 & $\begin{array}{l}\text {..I actively play around with concepts and } \\
\text { learning objects. }\end{array}$ & & & & & \\
\hline 44 & ... I am responsible for my learning. & $\mathrm{O}$ & $\mathrm{O}$ & $\mathrm{O}$ & $\mathrm{O}$ & $\mathrm{O}$ \\
\hline 45 & $\begin{array}{l}\text {.. my learning results depend on how much I } \\
\text { get engaged in activities. }\end{array}$ & $\mathrm{O}$ & $\mathrm{O}$ & $\mathrm{O}$ & $\mathrm{O}$ & $\mathrm{O}$ \\
\hline 46 & $\begin{array}{l}\text {... I construct my own meaning for concepts } \\
\text { and learning objects suggested by the teacher } \\
\text { and peer learners. }\end{array}$ & $\mathrm{O}$ & $\mathrm{O}$ & $\mathrm{O}$ & $\mathrm{O}$ & $\mathrm{O}$ \\
\hline 47 & $\begin{array}{l}\text {.. I am considered as a researcher and have to } \\
\text { look for information. }\end{array}$ & $\mathrm{O}$ & $\mathrm{O}$ & $\mathrm{O}$ & $\mathrm{O}$ & $\mathrm{O}$ \\
\hline 48 & $\begin{array}{l}\text {... information is given to me in an excessively } \\
\text { simplistic way. }\end{array}$ & $\mathrm{O}$ & $\mathrm{O}$ & $\mathrm{O}$ & $\mathrm{O}$ & $\mathrm{O}$ \\
\hline 49 & $\begin{array}{l}\text {...there is a good balance between information } \\
\text { given, coaching and information I have to look } \\
\text { for. }\end{array}$ & $\mathrm{O}$ & $\mathrm{O}$ & $\mathrm{O}$ & $\mathrm{O}$ & $\mathrm{O}$ \\
\hline
\end{tabular}

\section{4) Tutoring Support Structure (TSS)}

The Certificate course, the learning environment and the tutoring structure have been implemented using the TSS engineering tool. In terms of benefit and efficiency for the learner, give your opinion about the following statements. Please tick the appropriate circle on the scale (totally disagree - totally agree) for each statement.

\begin{tabular}{|c|c|c|c|c|c|c|}
\hline \multicolumn{2}{|c|}{ Statements: } & \multirow{2}{*}{$\begin{array}{c}\begin{array}{c}\text { Totally } \\
\text { disagree }\end{array} \\
\mathbf{1} \\
\text { O }\end{array}$} & \multirow{2}{*}{$\begin{array}{l}\text { Disagree } \\
\qquad \begin{array}{c}2 \\
\mathrm{O}\end{array}\end{array}$} & \multirow{2}{*}{$\begin{array}{c}\begin{array}{c}\text { Somewhat } \\
\text { agree }\end{array} \\
\mathbf{3} \\
\mathrm{O}\end{array}$} & \multirow{2}{*}{$\begin{array}{l}\text { Agree } \\
\qquad \begin{array}{l}4 \\
\text { O }\end{array}\end{array}$} & \multirow{2}{*}{$\begin{array}{c}\begin{array}{c}\text { Totally } \\
\text { agree }\end{array} \\
\\
\mathbf{5} \\
\mathrm{O}\end{array}$} \\
\hline 50 & $\begin{array}{l}\text { The director of the Certificate has always been } \\
\text { very present. }\end{array}$ & & & & & \\
\hline 51 & $\begin{array}{l}\text { Teachers and tutors were very present during } \\
\text { their module. }\end{array}$ & $\mathrm{O}$ & $\mathrm{O}$ & $\mathrm{O}$ & $\mathrm{O}$ & $\mathrm{O}$ \\
\hline 52 & $\begin{array}{l}\text { The human resources organisation : 1) director } \\
\text { of the Certificate, 2) teachers and tutors, } 3 \text { ) } \\
\text { pedagogical adviser, 4) technical support was } \\
\text { appropriate for this Certificate. }\end{array}$ & $\mathrm{O}$ & $\mathrm{O}$ & $\mathrm{O}$ & $\mathrm{O}$ & $\mathrm{O}$ \\
\hline 53 & $\begin{array}{l}\text { The teaching staff seems to have been trained } \\
\text { appropriately to support my learning. }\end{array}$ & $\mathrm{O}$ & $\mathrm{O}$ & $\mathrm{O}$ & $\mathrm{O}$ & $\mathrm{O}$ \\
\hline 54 & Teacher and tutor roles were clearly defined. & $\mathrm{O}$ & $\mathrm{O}$ & $\mathrm{O}$ & $\mathrm{O}$ & $\mathrm{O}$ \\
\hline 55 & $\begin{array}{l}\text { The community portal is an efficient learning } \\
\text { environment. }\end{array}$ & $\mathrm{O}$ & $\mathrm{O}$ & $\mathrm{O}$ & $\mathrm{O}$ & $\mathrm{O}$ \\
\hline 56 & $\begin{array}{l}\text { Accessing and using my peer learners' } \\
\text { productions was efficient for my learning. }\end{array}$ & $\mathrm{O}$ & $\mathrm{O}$ & $\mathrm{O}$ & $\mathrm{O}$ & $\mathrm{O}$ \\
\hline 57 & $\begin{array}{l}\text { Using templates for specific activities was } \\
\text { efficient for my learning. }\end{array}$ & $\mathrm{O}$ & $\mathrm{O}$ & $\mathrm{O}$ & $\mathrm{O}$ & $\mathrm{O}$ \\
\hline
\end{tabular}




\section{5) Tools}

During the Certificate's on-line modules, how often did you use the following tools? Please tick the appropriate circle on the scale (never - very often) for each tool.

\begin{tabular}{|llc|c|c|c|}
\hline Tools & & Never & $\begin{array}{c}\text { Not very } \\
\text { often }\end{array}$ & Often & Very often \\
& & $\mathbf{1}$ & $\mathbf{2}$ & $\mathbf{3}$ & $\mathbf{4}$ \\
\hline 58 & News & $\mathrm{O}$ & $\mathrm{O}$ & $\mathrm{O}$ & $\mathrm{O}$ \\
\hline 59 & Forum & $\mathrm{O}$ & $\mathrm{O}$ & $\mathrm{O}$ & $\mathrm{O}$ \\
\hline 60 & Chat & $\mathrm{O}$ & $\mathrm{O}$ & $\mathrm{O}$ & $\mathrm{O}$ \\
\hline 61 & Shoutbox & $\mathrm{O}$ & $\mathrm{O}$ & $\mathrm{O}$ & $\mathrm{O}$ \\
\hline 62 & Instant messenger- Pager & $\mathrm{O}$ & $\mathrm{O}$ & $\mathrm{O}$ & $\mathrm{O}$ \\
\hline 63 & Personal messages & $\mathrm{O}$ & $\mathrm{O}$ & $\mathrm{O}$ & $\mathrm{O}$ \\
\hline 64 & Wiki & $\mathrm{O}$ & $\mathrm{O}$ & $\mathrm{O}$ & $\mathrm{O}$ \\
\hline 65 & Calendar & $\mathrm{O}$ & $\mathrm{O}$ & $\mathrm{O}$ & $\mathrm{O}$ \\
\hline 66 & Journal & $\mathrm{O}$ & $\mathrm{O}$ & $\mathrm{O}$ & $\mathrm{O}$ \\
\hline 67 & Library & $\mathrm{O}$ & $\mathrm{O}$ & $\mathrm{O}$ & $\mathrm{O}$ \\
\hline 68 & Activity Folder & $\mathrm{O}$ & $\mathrm{O}$ & $\mathrm{O}$ & $\mathrm{O}$ \\
\hline 69 & Portal guide & $\mathrm{O}$ & $\mathrm{O}$ & $\mathrm{O}$ & $\mathrm{O}$ \\
\hline 70 & Portfolio & $\mathrm{O}$ & $\mathrm{O}$ & $\mathrm{O}$ & $\mathrm{O}$ \\
\hline 71 & Chat recording & $\mathrm{O}$ & $\mathrm{O}$ & $\mathrm{O}$ & $\mathrm{O}$ \\
\hline 71 bis & Module description (detailed scenario) & $\mathrm{O}$ & $\mathrm{O}$ & $\mathrm{O}$ & $\mathrm{O}$ \\
\hline 72 & $\begin{array}{l}\text { Forum awareness: did you use the "watch a topic" } \\
\text { functionality to receive an e-mail when new posts are }\end{array}$ & $\mathrm{O}$ & $\mathrm{O}$ & $\mathrm{O}$ & $\mathrm{O}$ \\
& added to a thread? & & & \\
\hline
\end{tabular}

Concerning awareness tools, how often did you look at the following tools? Please tick the appropriate circle on the scale (never - very often) for each tool.

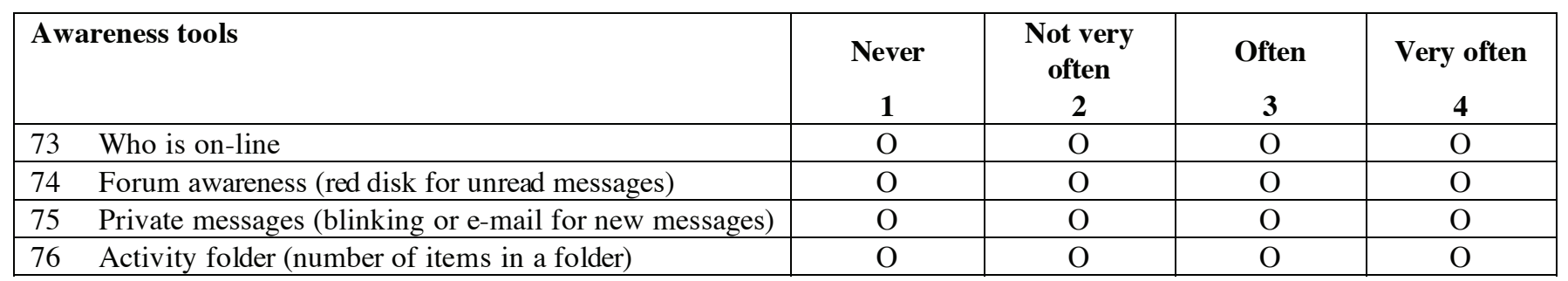

Have you noticed a change in your usage of the tools? Are there tools for instance that you used a lot in the beginning, but later discarded? Or, on the contrary, are there tools you discovered later on? Please tick the appropriate circle on the scale (used rather at the beginning - used only later on) for each tool. 


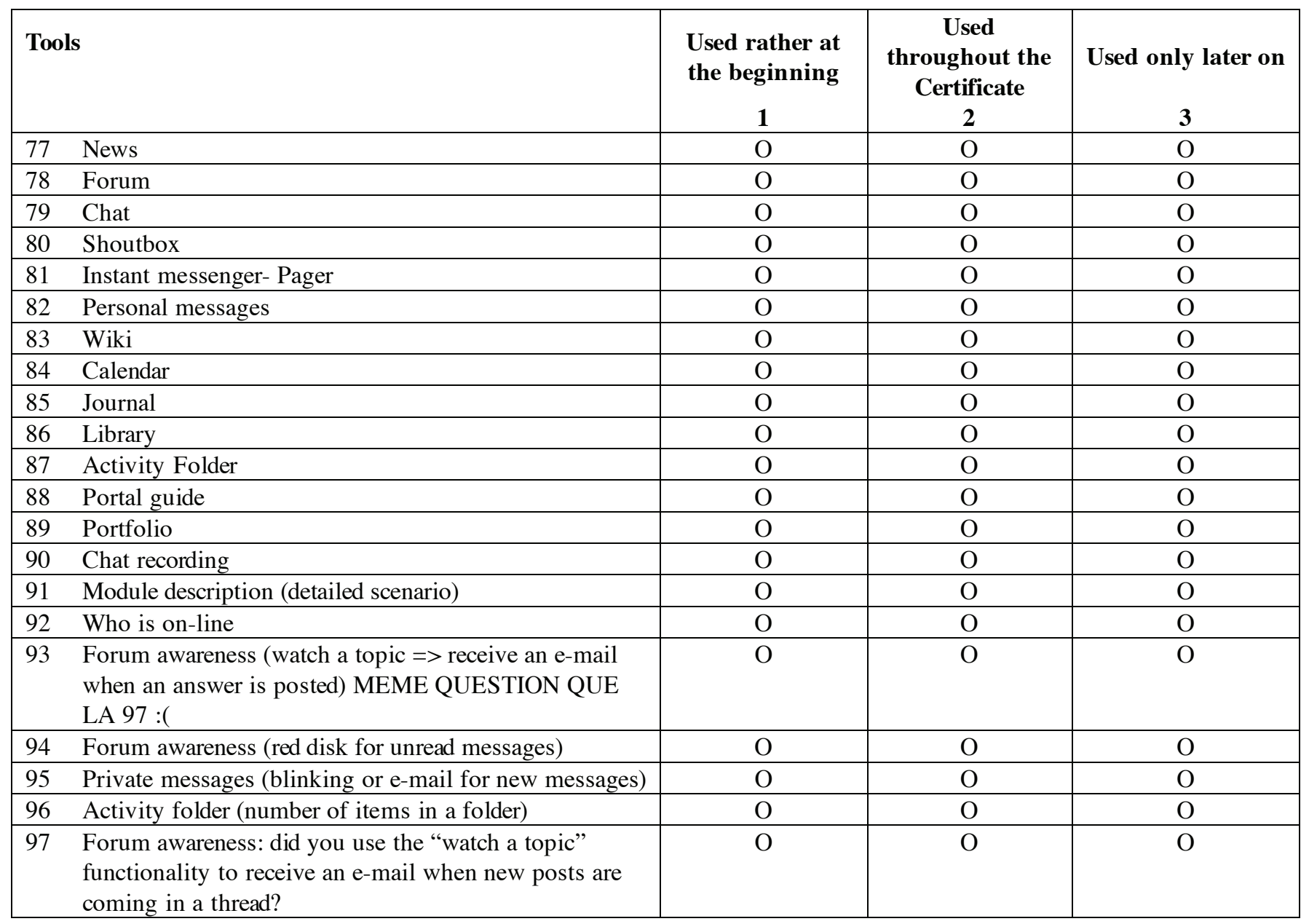


According to the pedagogical scenario and functionalities attributed to tools, do you think tools have fulfilled their "mission"? Please tick the appropriate circle on the scale (totally disagree - totally agree) for each statement.

\begin{tabular}{|c|c|c|c|c|c|c|c|}
\hline \multicolumn{2}{|c|}{ Tools } & $\begin{array}{c}\text { Strongly } \\
\text { disagree } \\
1 \\
\end{array}$ & $\begin{array}{c}\text { Disagree } \\
\\
2 \\
\end{array}$ & $\begin{array}{c}\begin{array}{c}\text { Somewhat } \\
\text { disagree }\end{array} \\
3 \\
\end{array}$ & $\begin{array}{c}\text { Some- } \\
\text { what } \\
\text { agree } \\
4 \\
4\end{array}$ & $\begin{array}{c}\text { Agree } \\
5 \\
\end{array}$ & $\begin{array}{c}\begin{array}{c}\text { Strongly } \\
\text { agree }\end{array} \\
6 \\
6\end{array}$ \\
\hline 98 & $\begin{array}{l}\text { News (beginning of new module, } \\
\text { synthesis) }\end{array}$ & $\mathrm{O}$ & $\mathrm{O}$ & $\mathrm{O}$ & & $\mathrm{O}$ & \\
\hline 99 & $\begin{array}{l}\text { Forum (elaborate and negotiate } \\
\text { knowledge, exchange information) }\end{array}$ & $\mathrm{O}$ & $\mathrm{O}$ & $\mathrm{O}$ & $\mathrm{O}$ & $\mathrm{O}$ & $\mathrm{O}$ \\
\hline 100 & $\begin{array}{l}\text { Chat (debriefing, regulation, } \\
\text { proximity communication) }\end{array}$ & $\mathrm{O}$ & $\mathrm{O}$ & $\mathrm{O}$ & $\mathrm{O}$ & $\mathrm{O}$ & $\mathrm{O}$ \\
\hline 101 & Shoutbox (spontaneous messages) & $\mathrm{O}$ & $\mathrm{O}$ & $\mathrm{O}$ & $\mathrm{O}$ & $\mathrm{O}$ & $\mathrm{O}$ \\
\hline 102 & $\begin{array}{l}\text { Instant messenger- Pager (call } \\
\text { someone present on the portal) }\end{array}$ & $\mathrm{O}$ & $\mathrm{O}$ & $\mathrm{O}$ & $\mathrm{O}$ & $\mathrm{O}$ & $\mathrm{O}$ \\
\hline 103 & $\begin{array}{l}\text { Personal messages (internal e-mail } \\
\text { messaging system) }\end{array}$ & $\mathrm{O}$ & $\mathrm{O}$ & $\mathrm{O}$ & $\mathrm{O}$ & $\mathrm{O}$ & $\mathrm{O}$ \\
\hline 104 & Wiki (co-elaborate documents) & $\mathrm{O}$ & $\mathrm{O}$ & $\mathrm{O}$ & $\mathrm{O}$ & $\mathrm{O}$ & $\mathrm{O}$ \\
\hline 105 & $\begin{array}{l}\text { Calendar (relevant course } \\
\text { information : meetings, starting of } \\
\text { new modules, etc. ) }\end{array}$ & $\mathrm{O}$ & $\mathrm{O}$ & $\mathrm{O}$ & $\mathrm{O}$ & $\mathrm{O}$ & $\mathrm{O}$ \\
\hline 106 & $\begin{array}{l}\text { Journal (reflexive, meta-cognitive } \\
\text { tool) }\end{array}$ & $\mathrm{O}$ & $\mathrm{O}$ & $\mathrm{O}$ & $\mathrm{O}$ & $\mathrm{O}$ & $\mathrm{O}$ \\
\hline 107 & Library (access digital resources) & $\mathrm{O}$ & $\mathrm{O}$ & $\mathrm{O}$ & $\mathrm{O}$ & $\mathrm{O}$ & $\mathrm{O}$ \\
\hline 108 & $\begin{array}{l}\text { Activity Folder (store learners' } \\
\text { productions) }\end{array}$ & $\mathrm{O}$ & $\mathrm{O}$ & $\mathrm{O}$ & $\mathrm{O}$ & $\mathrm{O}$ & $\mathrm{O}$ \\
\hline 109 & $\begin{array}{l}\text { Portal guide (support users with } \\
\text { information about tools and portal } \\
\text { philosophy) }\end{array}$ & $\mathrm{O}$ & $\mathrm{O}$ & $\mathrm{O}$ & $\mathrm{O}$ & $\mathrm{O}$ & $\mathrm{O}$ \\
\hline 110 & $\begin{array}{l}\text { Portfolio (centralise all important } \\
\text { productions, revisit one's learning } \\
\text { steps) }\end{array}$ & $\mathrm{O}$ & $\mathrm{O}$ & $\mathrm{O}$ & $\mathrm{O}$ & $\mathrm{O}$ & $\mathrm{O}$ \\
\hline 111 & $\begin{array}{l}\text { Chat recording (support memory and } \\
\text { give access) }\end{array}$ & $\mathrm{O}$ & $\mathrm{O}$ & $\mathrm{O}$ & $\mathrm{O}$ & $\mathrm{O}$ & $\mathrm{O}$ \\
\hline 112 & $\begin{array}{l}\text { Module description (detailed scenario } \\
\text { for each module to help you organise } \\
\text { your studies with your professional } \\
\text { commitments) }\end{array}$ & $\mathrm{O}$ & $\mathrm{O}$ & $\mathrm{O}$ & $\mathrm{O}$ & $\mathrm{O}$ & $\mathrm{O}$ \\
\hline 113 & Who is on-line (social awareness) & $\mathrm{O}$ & $\mathrm{O}$ & $\mathrm{O}$ & $\mathrm{O}$ & $\mathrm{O}$ & $\mathrm{O}$ \\
\hline
\end{tabular}

\section{6) Skills}

Below you will find statements about skills. Please tick the appropriate circle on the scale (totally disagree - totally agree) for each statement. Please fill in only the four questions that correspond to your situation: 1) not teaching yet while taking the Certificate course; OR 2) already a teacher while taking the Certificate course. 


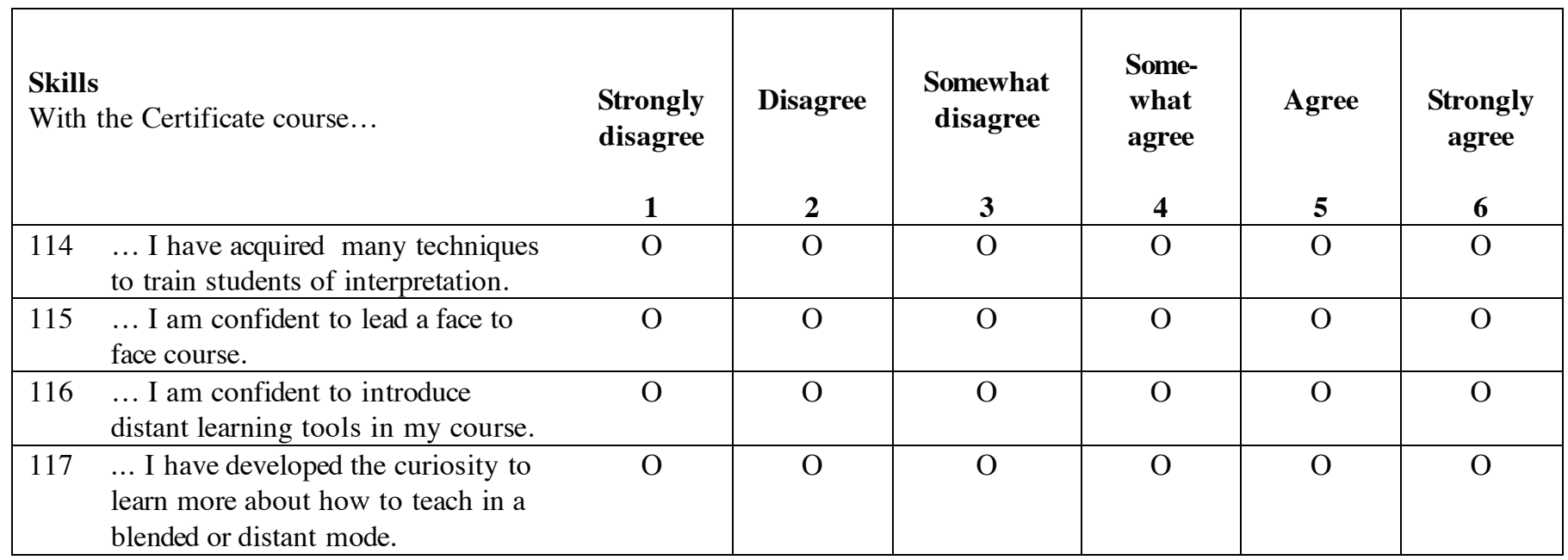

2) already a teacher while taking the Certificate course

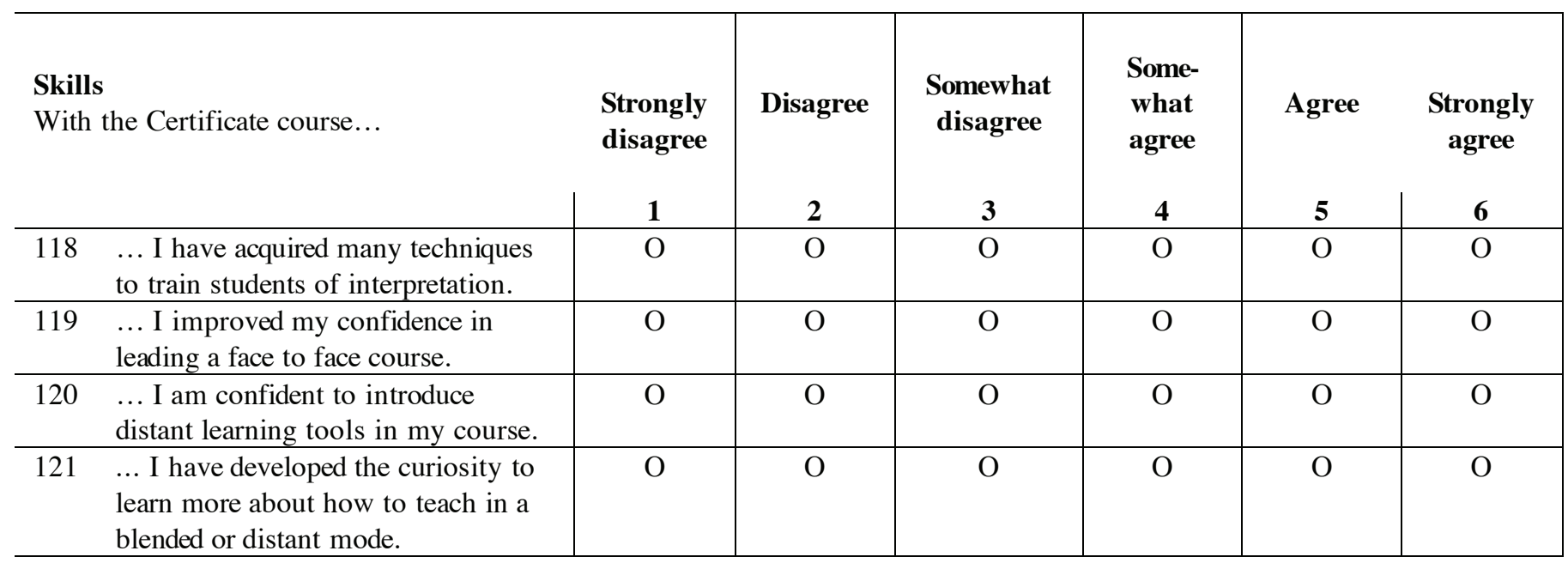

\section{7) Comments}

Thank you for your collaboration :) 


\section{8) Sources}

TAYLOR, P. and D. Maor (2000): Assessing the efficacy of online teaching with the Constructivist On-Line Learning Environment Survey, In A. HERRMANN and M.M. KULSKI (Eds), Flexible Futures in Tertiary Teaching. Proceedings of the 9th Annual Teaching Learning Forum, 2-4 February 2000, Perth, Curtin University of Technology.

Constructivist On-Line Learning Environment Survey (COLLES) questionnaire:

http://surveylearning.moodle.com/colles/

Dolmans, D.H.J.M., Wolfhagen, H.A.P., ScherpbieR, A.J.J.A. and C.P.M. VAn DeR Vleuten (2003).

Development of an instrument to evaluate the effectiveness of teachers in guiding small groups. Higher Education, 46, 431-446.

\section{9) Authors of the questionnaire}

Barbara Class

ETI - Ecole de Traduction et d'Interprétation

TECFA - TEChnologies de Formation et Apprentissage

Université de Genève

Faculté de Psychologie et des Sciences de l'Education

54 Route des Acacias,

1227 Genève - Suisse

Barbara.Class@tecfa.unige.ch

Tel: 41223799370

Fax: 41223799379

Daniel K. Schneider

TECFA - TEChnologies de Formation et Apprentissage

Université de Genève

Faculté de Psychologie et des Sciences de l'Education

54 Route des Acacias,

1227 Genève - Suisse

Daniel.Schneider@tecfa.unige.ch

Tel: 41223799377

Fax: 41223799379 